\title{
Analysis of the Effectiveness of the General Election Commission's Socialization as a Media for Political Education to Create a Democratic Society
}

\author{
Wandi Subroto \\ Sekolah Tinggi IImu Hukum Rahmaniyah Sekayu, Indonesia \\ Email: wandi.stihr@gmail.com
}

\begin{abstract}
The purpose of this study was to analyze the effectiveness of the socialization program carried out by the General Elections Commission as a medium of political education for the community. This study uses a type of juridical-normative research. The sources of law used in this study are secondary and tertiary sources of law. Sources of data were collected using questionnaires, interviews and literature studies. The location of this research was carried out at the General Election Commission office in Palembang. The data analysis method used in this study is a qualitative method which was collected during the research. The research respondents were 50 people who were selected using purposive sampling method. To maintain the validity of the data, field observation techniques and data triangulation techniques were used. Based on the results of the research data, it can be concluded that the socialization carried out by the General Election Commission of the city of Palembang was quite effective. This is supported by the strategy used, namely holding a political discussion forum, building an Election Smart House and carrying out direct outreach to novice voters who are in high school or equivalent, as well as two-way communication conducted by the General Election Commission of the city of Palembang.
\end{abstract}

Keywords: General Election Commission, Socialization, Political Education.

\section{A. INTRODUCTION}

Human Rights as basic rights owned by humans have a very broad scope and are inherent in every individual. The inherent rights require every individual to exercise and obtain their rights without exception, provided that they do not conflict with the rights of others. One of these rights is political rights (Amrizal et al., 2018). In relation to these political rights or sometimes known as political education, the 1945 Constitution as the constitution of the Republic of Indonesia has mandated that every citizen has the same position before the law and the government (Adnan et al., 2020). This is explained in Article 23 paragraph (1) and Article 43 of Law Number 39/1999 concerning Human Rights, this article provides the widest possible space for citizens to participate in government, exercise their right to vote and be elected in elections as well as their right to vote to join a political party.

Elections are always the main indicator of the existence of democracy in a country. Democracy literally means government by the people of the people and for the people (Ibrahim \& Madjid, 2018). The notion of democracy requires the participation and participation of the people or citizens in the activities of the 
administration of state life. Democracy in Indonesia is demonstrated by the existence of general elections held every five years to elect members of the legislature and president and their representatives which are held simultaneously throughout Indonesia and their representatives abroad (Rafni, 2020). This democratization is also seen in the direct election of regional heads.

General election activities (Election), which is one of the political activities that attract the most attention and involvement of the community so that elections become a very important moment of political education in order to mature citizens. Elections teach the public how to be involved in the political decision-making process by voting for certain political parties of their choice. Elections are a very important event in the democratic process to form a democratic government (Agus et al., 2021). The function of the general election is the establishment of the legitimacy of the rulers and the government, the formation of political representatives of the people, the circulation of the ruling elite, and political education (Amri et al.,2019).

In order for the general election to truly produce a democratic government, the general election should be held by an independent and impartial state institution (Print, 2020). Therefore, the General Elections Commission as the institution that organizes general elections in Indonesia must always adhere to the existing laws and regulations, the code of ethics and the rules of the General Election Commission (Haridison et al., 2021). The duties and authorities of the General Elections Commission in holding general elections are not solely related to the parties participating in the general election, but also to the public as voters in the general election.

In Law Number 15 of 2011 Article 1 paragraph (6) it is explained that the General Election Commission is a national, permanent, and independent election organizing body in charge of carrying out general elections. This article also explains about the Provincial General Election Commission and the Regency or City General Election Commission. Paragraph (7) of this article explains that the Provincial General Election Commission is the organizer of the general election in charge of carrying out general elections in the province, while the Regency/Municipal General Election Commission is the organizer of the general election in charge of carrying out general elections in the district/city (paragraph (8)).

Voter participation is very important in determining the success of the general election. For this reason, political education becomes a necessity to increase people's political knowledge so that they can participate optimally in the administration of state life (Muslim \& Citra, 2019; Waldi et al., 2018). In this regard, the General Elections Commission must also conduct political socialization to the public so that they are willing to use their voting rights when voting is carried out. Not only does it cost money, but energy and Human Resources, energy and thoughts from government officials and related parties are also needed extra to oversee the election agenda. Every time this agenda is implemented, there is a change in the number of enthusiasm and the number of people participating in the general election 
(Okunloye, 2017). The trend of voter turnout seems to have decreased, the trend of the voter turnout can be seen from the picture below:

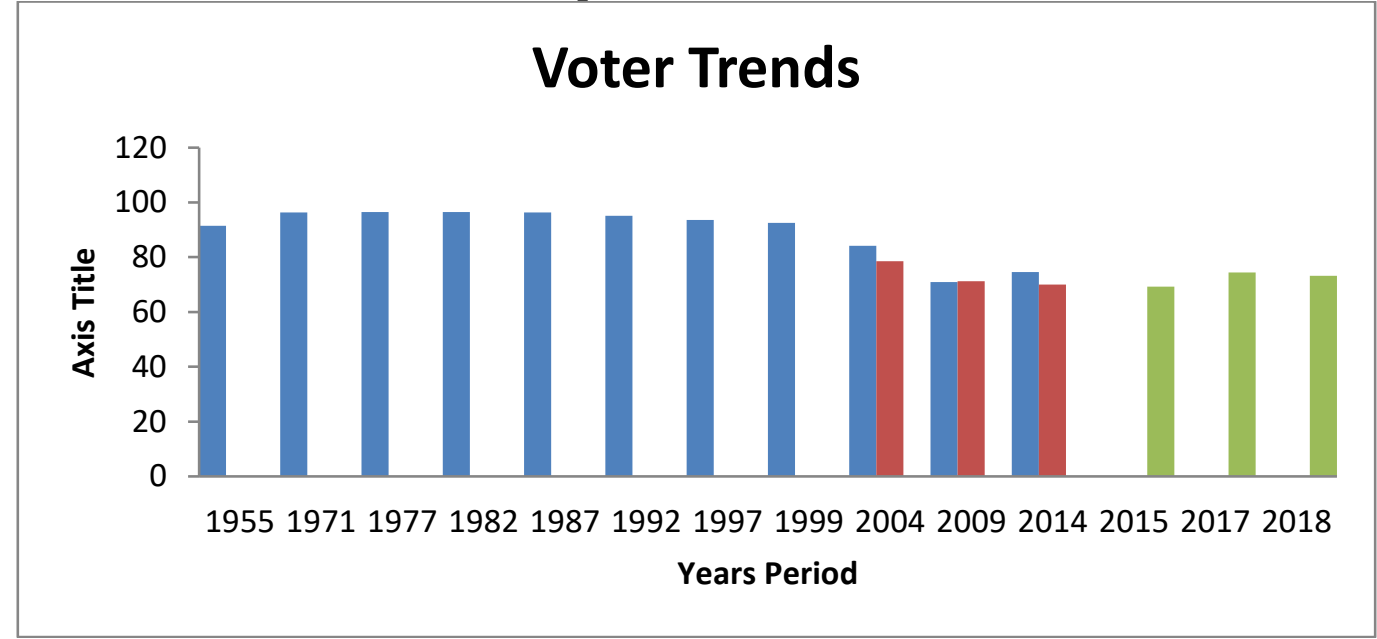

Figure 1. Trends in Voter Turnout from 1955-2018

Source: Founding Fathers Houses (FFH)

In a number of countries the theme of participation is an issue that is taken into account because it is closely related to the number of voters who attend and channel their voting rights and political rights through polling stations. Based on the ID-Vanhanen Index which is a combination of competition and participation variables, Vanhanen's research covers 187 countries in the period 1810-2000. Meanwhile, another index is the Freedom House Index (FFI) which is assessed using seven sub-categories, namely: 1) free to participate in the political process; 2) free to vote in a valid general election; 3) have a responsible representative; 4) freedom of opinion and worship; 5) have access to a fair system of rule of law; 6) get social freedom and 7) have economic freedom (Amechi et al., 2017). The results of this study have been published since 1972 and cover 192 countries.

Based on the data in Figure 1, the trend of participation rates in Indonesia seems to have decreased in the general election, presidential election or regional head election. Allegedly, the cause of the up and down trend in the participation rate is caused by various factors including minimal and ineffective socialization carried out by organizers such as the selection of socialization media, dissemination of knowledge, segmentation, choice of voter communication techniques, and poor technical during the voting stage and other factors. This poor socialization has a very significant impact on student participation (Agus et al., 2021). In general, students are aware of the implementation of general elections with numbers reaching more than $92 \%$ but do not know the exact time of the election, this is reinforced by the data presented in the following figure: 


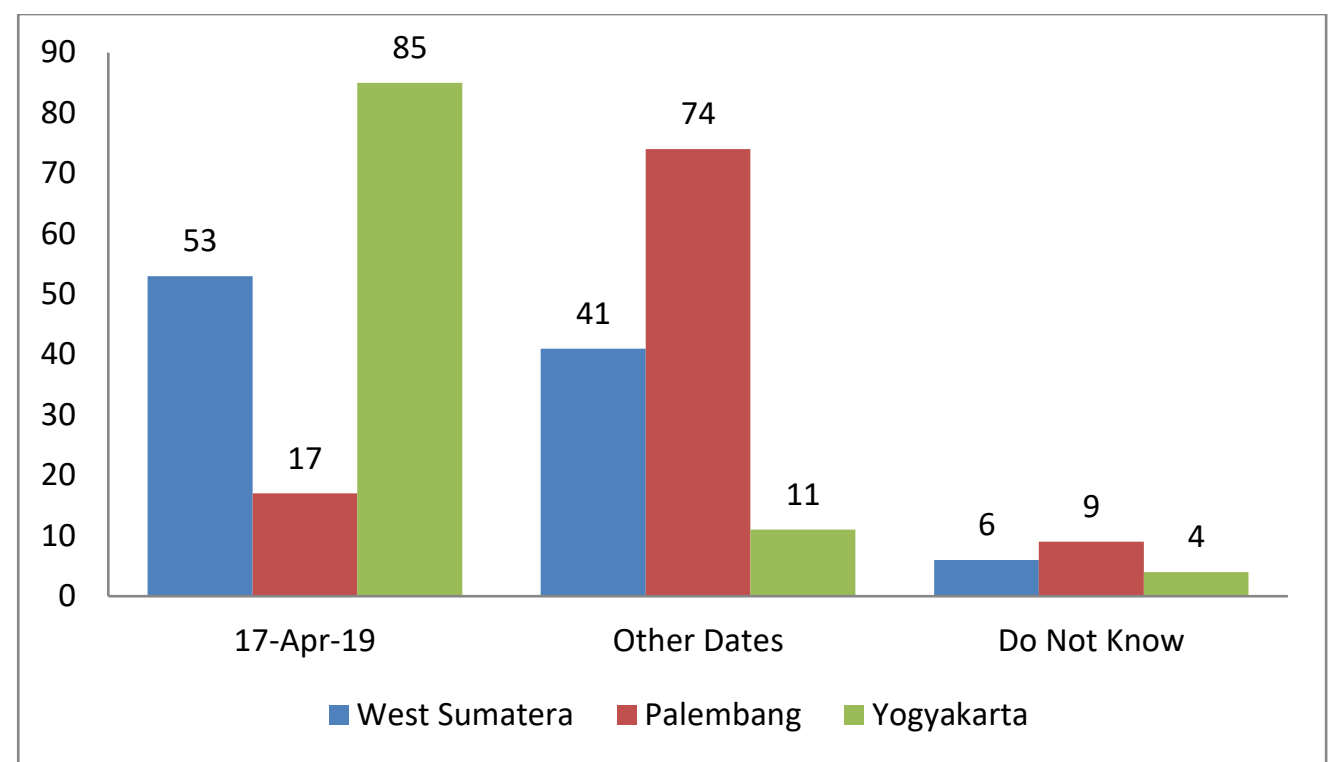

Figure 2. Table of Student Knowledge about the Implementation of the 2019 General Election

Source: Founding Fathers House (FFH)

Based on these data, it can be seen that the socialization carried out by the General Elections Commission is still very ineffective, so it needs improvements and other strategies that can be an option to optimize it. Basically community political participation in general elections can be a means or media used by the community to control the government that will be elected. The community has the right to determine and submit their mandate to those who are worthy and trusted to run the wheels of government in the future a tool to express the existence of individuals or social groups in society by influencing the government through political mechanisms (Syaifuddin, 2020).

The low level of political participation generally arises because of apathy and a priori attitudes towards political activities and activities, where people prefer to carry out their daily activities such as work, sports, social clubs, sightseeing and so on, which are felt to provide a more tangible benefit compared to having to do activities. participate in politics (Okunloye, 2017; Pahlevi, 2019). Another factor that is also closely related to political participation is the level of public education, where the higher the education level of the community, usually it will be directly proportional to their tendency to participate in politics (Nurvianti et al., 2019). This is the irony in many developing countries, where the level of public literacy is still low, thus affecting the level of public participation on the political agenda which is generally relatively low.

The existence of the General Election Commission as the organizer of the general election is also required to be professional, accountable, and with high integrity, because it has a very important strategic value. The General Election Commission is tasked with preparing legal instruments to ensure that voters can exercise their right to vote. As stated in one of the mission points of the General Elections Commission, namely: Increasing people's political awareness to actively 
participate in general elections for the realization of the ideals of a democratic Indonesian society.

\section{B. LITERATURE REVIEW}

\section{Effectiveness of Socialization as a Media for Political Education}

Socialization can be understood as a learning process. In a political process, political socialization can be an important thing because there is the involvement of individuals with various groups in a system to participate in the political process that occurs. Broadly, political socialization is a transmission from political culture to a new generation in a society (Ibrahim \& Madjid, 2018).

In another understanding, political socialization refers to various processes that shape political attitudes as well as change patterns of behavior that occur in society. Political socialization also creates a process of cultural transmission, namely by passing down political standards and beliefs from generation to generation. Political socialization is a product of interrelated micro and macro phenomena (Setyagama, 2021). The basic question at the macro level in political socialization research is how does the political community pass on values, attitudes, beliefs, and opinions and behaviors to society? Studies of political socialization at the micro level ask: how and why do people become citizens? At the macro level of the political system, political socialization is a tool used by the political community to instill appropriate norms and practices into its citizens. While at the micro level, political socialization is the patterns and processes that individuals go through in engaging themselves in political development and learning, forming a special context with the political environment in which they live (Nurvianti et al., 2019).

Political socialization can be understood in a broad and narrow sense, namely: 1) In a narrow sense, political socialization is the intentional inculcation of information, values and practices for which the instructional body is formally assigned responsibility; and 2) In a broad sense, political socialization is all efforts to learn, whether formal or informal, intentional or unplanned, at every stage of the life cycle, and includes not only explicitly learning problems, but also nominally learning to behave about characteristics the personality characteristics in question (Setyagama, 2021).

From some of the views of the experts above, there are at least similarities which show that basically political socialization is a process of how to introduce a political system to a person, and how that person determines his responses and reactions to political phenomena (Soedarwo et al., 2020). Political socialization thus also shows how each member of society should participate in the political system.

\section{Types of Political Socialization}

There are various types of political socialization, and if it is associated with the process, socialization can be divided into two types, namely: (1) Primary socialization, the first socialization that individuals undergo as a child by learning to become members of the community (family). This socialization takes place in 
childhood. (2) Secondary socialization, is a further socialization process after primary socialization that introduces individuals to certain groups in society. Both processes take place in the total institution, namely the place of residence and place of work (Amalia et al.,2021). In both institutions, there are a number of individuals in the same situation, separated from the wider community for a certain period of time, living together in the process of life, and formally regulated.

Meanwhile, based on the type, the types of socialization are divided into two, namely: (1) Formal socialization, namely socialization carried out through authorized institutions according to state regulations or through institutions established according to applicable laws and government regulations; and (2) Informal socialization, namely socialization that is familial, friendship or informal. Socialization carried out by government institutions, such as the General Election Commission, is called formal socialization because the institution has the authority and has a legal basis, besides the material presented by the institution is government policy (Septiadi et al., 2021). Formal socialization is the type that is often used by the government in disseminating newly created programs or policies to the public, such as the General Election Commission in disseminating the general election process.

\section{METHOD}

This study uses a type of juridical-normative research. The sources of law used in this study are secondary and tertiary sources of law. Sources of data were collected using questionnaires, interviews and literature studies. The location of this research was carried out at the General Election Commission office in Palembang. The data analysis method used in this study is a qualitative method which was collected during the research (Erlina, 2020). The research respondents were 50 people who were selected using purposive sampling method. To maintain the validity of the data, field observation techniques and data triangulation techniques were used.

\section{RESULT AND DISCUSSION}

\section{The Role of the Palembang City General Election Commission in Political} Education

As a country that adheres to a democratic system, democracy is currently seen as the best instrument it has because it involves the community in making decisions about the running of a government system. The General Election Commission of the city of Palembang has an important role in the democratic party at the Palembang city level as well as an institution that is obliged to provide political education for the community. In this case, the duties and authorities of the General Elections Commission include 1) planning and preparing for the implementation of general elections, 2) receiving, researching, and determining political parties that have the right to run in general elections; 3) establish the Indonesian Election Committee; 4) coordinating General Election activities from the central to regional levels; 5) determine the number of seats for the members of the People's Representative 
Council, Regional People's Representative Council I and Regional People's Representative Council II for each electoral district; 6) determine the overall results of general elections in all electoral districts for the People's Representative Council, Regional People's Representative Council I and Regional People's Representative Council II; 7) collect and systematize materials and data on general election results; 8) lead the stages of general election activities; and carry out socialization regarding the holding of general elections or those related to the duties and authorities of the General Elections Commission to the public.

This function is a basic function that is assigned to the General Election Commission because its inputs and outputs are a prerequisite for the operation and operation of the General Election Commission. With political education, it is hoped that it will increase public participation in every election. The roles carried out by the General Election Commission of the city of Palembang in providing political education for the community are as follows:

a. Hold a political discussion forum. Awareness for the fulfillment of political education for the wider community must be carried out. Therefore, the General Election Commission of the city of Palembang facilitated this by holding regular political education discussions. The community is invited to share their ideas and hopes that are conveyed in the forum, it is hoped that there will be easy access in the implementation of elections, both using their right to vote and accessing other information.

b. Making Election Smart Houses. Making Election Smart Houses. In the context of the efforts of the Palembang City General Election Commission in increasing voter participation, the Palembang City General Election Commission built the Election Smart House with the aim of being expected to become part of political education for the general public, public awareness and inspiration on the importance of elections and democracy will be provided. This smart house is also very important for the dissemination of the General Elections Commission by the General Elections Commission.

c. Carry out direct socialization among high school students or equivalent as an introduction to novice voters to be actively involved and participate in democratic parties.

Political socialization in a larger framework is related to a larger framework related to the interests of the Indonesian nation in order to create a democratic government. A democratic government can only be realized if civil society is strong or empowered. This socialization activity is not carried out alone by the General Election Commission. In general, all political institutions play a role in political socialization, including state institutions, Bapilu (Election Oversight Body) at the national level, Election Supervisory Committees at the district/city level, and especially political parties. Therefore, the General Elections Commission must always maintain communication with various government agencies as well as with political parties participating in the general election. 
The role of the General Elections Commission in political socialization is confirmed in the Election Law No. 22 of 2007 concerning General Election Organizers in article 8 paragraph (1) letter q: carry out socialization regarding the implementation of general elections and or related to the duties and authorities of the General Election Commission to the public. Especially for the Regency/Municipal General Election Commission, its role in socialization is emphasized in Article 10 letter o: carrying out socialization regarding the implementation of general elections and/or relating to the duties and authorities of the Regency/City General Election Commission to the public.

In its role as a place for political education, aspects that are socialized by the General Election Commission of the city of Palembang are the benefits of the general election, names of general election participants, invitations to vote later at the time of voting, general election procedures, general election schedule, especially at the time of voting. campaign stage, voting procedures, voting schedule and announcement of vote counting results (Malik et al., 2020). Messages in socialization activities need to be interesting, informative, simple, and easy to understand. The socialization media is also supported by various additional techniques, including voting simulations, placing advertisements in print and electronic media, outdoor advertising for example by placing billboards in strategic places, distributing brochures, stickers, and so on. In order to carry out socialization of the general election, the General Election Commission of Palembang city adheres to the ethics of implementation. To realize this attitude, the General Elections Commission must comply with the General Election Implementing Code of Ethics.

\section{Effectiveness of Interactional Socialization (Reciprocal) and Directional Socialization}

In several socialization activities carried out to attract the attention of novice voters in several high schools or equivalent, the General Election Commission of the city of Palembang emphasized the importance of being involved in the general election. In addition, this was also done by visiting several elements of the community who really needed counseling in order to have political awareness and awareness of democracy, but the General Election Commission of Palembang city mostly functions as a coordinator, so the activities carried out in the form of activity programs for the community are not optimal. The effectiveness of political socialization carried out by the General Election Commission of Palembang city is presented in the following table:

Table 1. The Results of the Questionnaire on the Effectiveness of Political Socialization

\begin{tabular}{|c|c|c|c|}
\hline \multirow{2}{*}{ Variable Measure } & \multicolumn{3}{|c|}{ Percentage of Answers } \\
\cline { 2 - 4 } & Low & Medium & High \\
\hline Submission Technique & $13 \%$ & $30 \%$ & $57 \%$ \\
\hline Socialization Channel & $27.5 \%$ & $25.7 \%$ & $46.8 \%$ \\
\hline
\end{tabular}




\begin{tabular}{|c|c|c|c|}
\hline Socialization Object & $17.4 \%$ & $42.6 \%$ & $39 \%$ \\
\hline Impact of Socialization & $19.3 \%$ & $39.7 \%$ & $41 \%$ \\
\hline Socialization Material & $17.5 \%$ & $46.8 \%$ & $35.7 \%$ \\
\hline
\end{tabular}

\section{Source: Data Proceed}

Based on the research data, the socialization carried out by the General Election Commission of the city of Palembang was classified as effective (41.7\%). It can be seen that: 1) In the socialization, the respondents agreed that $56 \%$ of the respondents agreed, this means that the respondents considered the invitation and the technical selection to be conveyed during the socialization; 2) Then with what channel, it is explained that $46.7 \%$ of the channels have been used effectively, which means either directly or indirectly informing the public about the implementation of the general election; 3) 39\% of respondents considered to whom information about general elections was conveyed as expected; 4) And the effect that is felt is also $41 \%$ effective as a result of the socialization carried out by the General Election Commission of the city of Palembang; 5) However, the public still does not know that it is the General Elections Commission that conducts the socialization, with $35.7 \%$ of respondents answering neutral.

In addition, the form of communication carried out by the General Election Commission of the city of Palembang uses a form of symbolic interactional communication because it is considered more dynamic than one-way communication, because this form of socialization can further explore problems, the content of the message can be packaged in a persuasive and flexible manner based on the context of the communication media used. In addition, the feedback process between the encoder and decoder can ensure that the message conveyed is truly in accordance with the purpose of the sender of the message. However, interactional communication theory tends to involve participants in a limited manner, so that the reach of message recipients only consists of certain groups. This is what has been done by the General Election Commission of the city of Palembang, where the General Election Commission of the city of Palembang has carried out the Duties and Authorities of Law Number 11 of 2008 concerning the General Election Commission (General Election Commission). Interactional socialization activities are not only carried out in the form of face-to-face meetings, but are also carried out through dailogical communication media which are carried out through television and radio media interactions which are broadcast live in the Political Dialogue Program.

In another form. The General Election Commission of Palembang city also uses one-way communication media, including pamphlets/posters, brochures, banners, as well as through public information media news such as public service advertisements broadcast through online media, including website pages, Facebook, Twitter or Instagram. One-way communication seems to be much more efficient and effective in disseminating encoder messages to decoders, where in this context the encoder or message sender is represented by the General Election Commission of 
Palembang city which then packs the message (content) in a language that has been determined by default, through the media. certain to be accepted by the decoder, which in this case is the wider community. One-way communication (directional) there is no feedback, so the content of the message is standard and not flexible, which must be packaged properly so that it can represent the purpose of the sender of the message, in its delivery it must use language that is easy to understand, and can attract the attention of the decoder to listen. the content of the message in more depth, so that the purpose of the sender of the message can be interpreted as it is. In this communication, the decoder party is generally fragmented or segmented based on the type of communication media used, and depending on the taste of the decoder party in accessing which channel it wants and likes, or the channel it usually uses to receive information sources, such as television viewers.

\section{E. CONCLUSION}

Based on the results of the research data, it can be concluded that the socialization carried out by the General Election Commission of the city of Palembang was quite effective. This is supported by the strategy used, namely holding political discussion forums, building Election Smart Houses and carrying out direct outreach to novice voters who are in high school or equivalent, as well as two-way communication carried out by the General Election Commission of the city of Palembang which is an influential factor. on the effectiveness of socialization as a medium of political education.

\section{REFERENCES}

1. Adnan, I. Z., Kurniawan, A. W., Raturahmi, L., \& Latifah, H. (2020). Local Elections in the Social Media Era (Socialization of Local Election through SocialMedia for Beginner Voters by Garut Regency Election Commission in 2018 Regional Election). KnE Social Sciences.

2. Agus, B. S., Astuti, R. S., \& Sardini, N. H. (2021). Election Governance Based on Public Participation in Indonesia. Multi-cultural Education, 7(6).

3. Amalia, Z. N., Ulya, R. W., Hastuti, D. R., \& Mardianto, M. F. F. (2021). Structural Equation Modeling in Motivation Analysis for Millennial Participation Related to General Elections in Indonesia. ESTIMASI: Journal of Statistics and Its Application, 29-37.

4. Amechi, O. R., Innocent, E. O., \& Ikechukwu, A. (2018). Political education in Nigeria: the mobilisation theory thesis perspective. Art Human Open Acc J, 2(5), 246-256.

5. Amri, E., Susilawati, N., \& Fernandes, R. (2019, September). Integrating The Voter Education to School Subjects in Formal Education. In The International Conference on ASEAN (pp. 464-471).

6. Amrizal, D., Yusriati, Y., \& Lubis, H. (2018). The Role of General Election Commission (KPU) in Increasing Voters' Participation in Langkat, Medan, 
Indonesia. Budapest International Research and Critics Institute (BIRCI-Journal): Humanities and Social Sciences, 1(2), 13-24.

7. Erlina; N. N. (2020). Gender Analysis in Indonesia's Legislation Regarding Political Laws. Lentera Hukum, 7, 337.

8. Haridison, A., Sandi, J. R. A., Suprayitno, S., \& Jaya, I. (2021). Regional Election and Covid-19: Evidence in Central Kalimantan. Budapest International Research and Critics Institute-Journal (BIRCI-Journal) Vol, 4(2), 1597-1606.

9. Ibrahim, A. H. H., \& Madjid, S. (2018). The role of political parties on election commission performance in 2015 mayor election of Ternate city. International Journal of Scientific \& Technology Research, 7(2), 118-123.

10. Ibrahim, A. H. H., \& Madjid, S. (2018). The role of political parties on election commission performance in 2015 mayor election of Ternate city. International Journal of Scientific \& Technology Research, 7(2), 118-123.

11. Malik, A., Supriyono, B., \& Mindarti, L. I. (2020). Direct and Simultaneous Regional Head Election in Indonesia with Government Efforts to Build a Balance of Political and Managerial Approaches. East Asia, 37(3), 261-279.

12. Memon, S., Ishak, M. S. B., \& Hamid, N. B. A. (2017). The Influence of Political Socialization Agents on Political Participation of Pakistani Youths. Jurnal Ilmiah LISKI (Lingkar Studi Komunikasi), 3(2), 130-149.

13. Muslim, N., \& Citra, P. (2019). Socializing the constitution: Malaysian national agenda. Asian Soc. Sci, 15(11), 35-41.

14. Nurvianti, D., Makka, Z., \& Zein, Y. A. (2019). Legal Protection for Person with Disabilities in Relating Right to Vote on the Indonesian Election. the int. jou. soc. hum. inve, 6(10), 5674-5678.

15. Okunloye, R. W. (2017). Exploring Non-formal Political Education Programme for Addressing Political Apathy and Irrational Voting Behaviour in Nigeria's 4th Republic. KIU Journal of Social Sciences, 3(2), 37-42.

16. Pahlevi, O., Suryadi, B., \& Jamaluddin, J. (2019). Election Behavior in Communities of Mentaya River Flows in Legislative General Election In 2014 Baamang Subdistrict, Indonesia. European Journal of Political Science Studies.

17. Print, M. (2020). Political socialization in a failed democracy: Civic education in Thailand. PCS-Politics, Culture and Socialization, 8(1+2), 9-10.

18. Rafni, A. (2020, August). Political Education for Novice Voters Through Students' Democracy Jamboree Program. In International Conference on Social Studies, Globalisation and Technology (ICSSGT 2019) (pp. 115-123). Atlantis Press.

19. Septiadi, M. A., Salsabilla, A., Bernadib, B., \& Nugraha, L. (2021). The Imperative Power of Election Law on Money Politics. Soshum: Jurnal Sosial dan Humaniora, 11(2), 112-119.

20. Setyagama, A. (2021). Strengthening Local Democracy Through Election Regional Head Directly in Indonesia. Multicultural Education, 7(8).

21. Soedarwo, V. S. D., Jha, G. K., Yumitro, G., \& Zuriah, N. (2020). Gender Sensitivity among Political Parties in Indonesia and India. KnE Social Sciences, 8192. 
22. Syaifuddin, A. C. I. (2020). Political Identity: The Bargaining of Center Politic Party Spectrum on the Selection of Indonesian vice President in 2019 General Election (Literature Study: The Candidacy of Jokowi's vice President Candidate). International Journal of English Literature and Social Sciences (IJELS), 5(1).

23. Waldi, A., Miyato, M., Montessori, M., Nazirwan, N., Ibrahim, R., \& Sabiruddin, S. (2018). The strategy of political parties in wining legislative elections in indonesia: studies in dharmasraya district. IJMURHICA: International Journal of Multidisciplinary Research of Higher Education, 1(1), 18-31.

24. Waldi, A., Miyato, M., Montessori, M., Nazirwan, N., Ibrahim, R., \& Sabiruddin, S. (2018). The strategy of political parties in wining legislative elections in indonesia: studies in dharmasraya district. IJMURHICA: International Journal of Multidisciplinary Research of Higher Education, 1(1), 18-31. 